\title{
Effects of gelatinized anionic salts in prepartum diets of dry cows on feed intake, urinary $\mathrm{pH}$, and serum parameters
}

\author{
W. Gao', L. Shi, P.-F. Zhang, A. Yu, D.-S. Wang and M.-Q. Li \\ College of Animal Science and Technology, Shihezi University \\ Shihezi 832003, P. R. China
}

\begin{abstract}
Nine multiparous cows were fed diets containing gelatinized anionic salts to determine the effects of acidified diet on dry matter intake (DMI), urinary $\mathrm{pH}$, and serum parameters. Dietary cationanion difference (DCAD) for precalving diets was approximately $+10,-2$, and -10 meq/100 g DM, respectively. There were no differences on DMI of cows fed the acidified diet compared with $\mathrm{DCAD}+10(\mathrm{P}>0.05)$. Mean serum $\mathrm{Ca}$ concentrations were increased for cows fed the DCAD-10 $\operatorname{diet}(\mathrm{P}<0.0001)$. Urinary $\mathrm{pH}$ of cows fed DCAD-2 and DCAD-10 diets were decreased compared with $\mathrm{DCAD}+10(\mathrm{P}<0.0001)$. These data indicate that a diet based on reed hay and maize silage supplemented with gelatinized anionic salts with a DCAD value $-10 \mathrm{meq} / 100 \mathrm{~g}$ DM is suitable for prepartum dairy cows.
\end{abstract}

KEY WORDS: hypocalcaemia, dietary cation-anion difference, anionic salts, dry cow

\section{INTRODUCTION}

During the last two decades, a number of documents have demonstrated that addition of anionic salts in precalving diet to lower the cation-anion difference (DCAD) value negatively can prevent milk fever (Beede et al., 1992). Although the mechanism by which anionic salts burnish periparturient $\mathrm{Ca}$ status is unclear, several mechanisms are interconnected and responsible for the preservation of a constant concentration of circulating Ca (Goff et al., 1988). Acidified diets by anionic salts cause sub-acute metabolic acidosis that may mediate the release of $\mathrm{Ca}$ from the bone, enhance $\mathrm{Ca}$ uptake from the intestine, and cause a excretion of Ca through the urine (Fredeen et al., 1988).

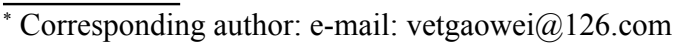


Because of the poor palatability of anionic salts, the addition of anionic salts in the precalving diet commonly cause dry matter intake (DMI) of dry cows to decline dramatically. Oetzel and Barmore (1993) observed a dramatic reduction in acceptability when $2.3 \mathrm{eq} / \mathrm{d}$ of anionic salts were included in a concentrate mixture. So, how to overcome this drawback of anionic salts to further broaden the application of anionic salts is worth to be further studied. The purpose of this study was to evaluate the effects of gelatinization of anionic salts on DMI, urinary $\mathrm{pH}$, and blood parameters of dry cows.

\section{MATERIAL AND METHODS}

\section{Experimental cows and treatments}

Gelatinized anionic salts were composed with ammonium chloride, calcium chloride, magnesium sulphate, calcium sulphate, magnesium oxide, maize starch and molasses. Nine multiparous pregnant, nonlactating Holstein cows were brought into maternity pens before $4 \mathrm{wk}$ prior to the predicted date of parturition. Cows were allocated randomly to three treatment diets on the basis of total production for the previous lactation, age and liveweight. The forages fed to cows consisted of chopped reed hay available freely and $10 \mathrm{~kg}$ maize silage (as-fed basis) daily per cow. Cows were allotted randomly to be individually fed one of three concentrate mixtures. Concentrate 1 was designed to be a standard dry cow concentrate mixture with a DCAD of $+9.72 \mathrm{meq} / 100 \mathrm{~g} \mathrm{DM}$ for the diet (DCAD+10). Concentrates 2 and 3 were supplemented with 1.87 and $3 \%$ gelatinized anionic salts of the diet with a DCAD of -2.40 (DCAD-2) and -9.64 (DCAD-10) meq/100 g DM, respectively. Diets were fed for ad libitum intake three times daily at 7.00, 13.00 and $19.00 \mathrm{~h}$, and DMI was measured at $-19,-15,-12,-8,-5$ and -1 day relative to parturition. Cows had free access to water throughout the trial.

\section{Sampling and laboratory analysis}

Blood samples from jugular were collected from each cow $2 \mathrm{~h}$ after the morning feeding on the day $21,18,15,12,9,6,4,2$ and 0 prior to calving and day 2,4 and 6 postpartum. The blood samples were allowed to clot at room temperature and was centrifuged $(4000 \mathrm{~g}$ ) to allow separation of the serum and were stored at $-20^{\circ} \mathrm{C}$ for subsequent analysis. Midstream urine samples were collected daily in the morning. Urine samples $(10 \mathrm{ml})$ were analysed for $\mathrm{pH}$ within $1 \mathrm{~h}$ of collection using a $\mathrm{pH}$ meter (model PHS-3C).

Parathyroid hormone (PTH) concentrations in serum were determined by an immunoradiometric assay (PTH-M44-68 kit). Concentrations of hydroxyproline 
(Dabev and Struck, 1971), creatinine (Bartels et al., 1972) and P (Weissman and Pileggi, 1974) in serum were determined by colorimetric procedures. Concentrations of $\mathrm{K}, \mathrm{Na}, \mathrm{Ca}, \mathrm{Mg}$ in serum were analysed via atomic absorption spectrophotometry.

\section{Statistical analysis}

All data were analysed by general linear models procedures of SAS (1985) for ANOVA to evaluate differences among the three experimental groups, and the Duncans multiple range test was performed to compare the groups.

\section{RESULTS AND DISCUSSION}

Chemical composition of the diets indicated that they were matched in CP, fibre, energy, $\mathrm{Ca}, \mathrm{Mg}, \mathrm{Na}, \mathrm{K}, \mathrm{Cl}, \mathrm{S}$, and $\mathrm{P}$. The DCAD content of all diets containing anionic salts was below $0 \mathrm{meq} / 100 \mathrm{~g} \mathrm{DM}$, which is considered to be important in the prevention of milk fever.

On the whole, there were no significant differences in DMI among the groups $(\mathrm{P}>0.05)$. This result as well as the observation of feeding behaviour of cows that consume diets containing anionic salts revealed that the palatability of anionic salts was obviously improved by the gelatinization with maize starch and molasses.

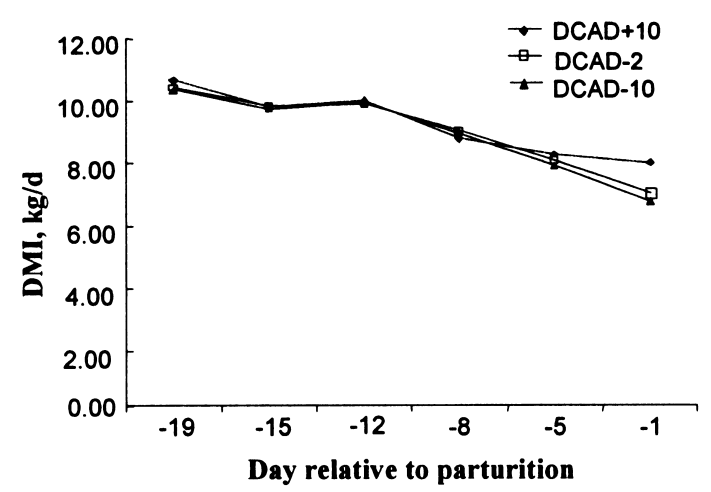

Figure 1. Means of daily dry matter intake (DMI) as affected by treatments

Serum ionized Ca concentrations of cows fed DCAD-10 diet were significantly increased compared with the cows fed the DCAD-2 and DCAD +10 diets (Table 1; $\mathrm{P}<0.001$ ). Similar results of raised concentration of $\mathrm{Ca}$ in blood and serum caused by the negative DCAD diets have been reported (Joyce et al., 1997). Serum P 
concentration had no significant differences among the three groups $(\mathrm{P}>0.05)$. However, results of previous experiments have been contradictory in respect of changes in P in serum and plasma caused by anionic salts (Beede et al., 1992).

The concentrations of hydroxyproline in serum of cows fed DCAD-2 and DCAD-10 diets were reduced significantly compared with DCAD +10 , which is inconsistent with Joyce et al. (1997). This result indicates that the improved Ca status of cows fed anionic salts might have been due to the increased absorption of $\mathrm{Ca}$ from the intestine, not have been due to the hydrolysis of bone tissue.

Table 1. Effects of anionic salts on the serum parameters

\begin{tabular}{lccccc}
\hline Item & DCAD+10 & DCAD-2 & DCAD-10 & SEM & P \\
\hline $\mathrm{PTH}, \mathrm{ng} / \mathrm{dl}^{1}$ & 21.14 & 19.86 & 14.28 & 3.91 & 0.4216 \\
$\mathrm{Hy}, \mathrm{mg} / \mathrm{l}^{2}$ & $21.81^{\mathrm{a}}$ & $15.83^{\mathrm{b}}$ & $16.14^{\mathrm{b}}$ & 1.40 & 0.0041 \\
$\mathrm{Ca}, \mathrm{mg} / \mathrm{dl}$ & $9.63^{\mathrm{a}}$ & $9.95^{\mathrm{a}}$ & $12.48^{\mathrm{b}}$ & 0.37 & 0.0001 \\
$\mathrm{P}, \mathrm{mg} / \mathrm{dl}$ & 5.40 & 6.37 & 6.00 & 0.33 & 0.1226 \\
$\mathrm{Mg}, \mathrm{mg} / \mathrm{dl}$ & 2.93 & 2.99 & 2.81 & 0.11 & 0.4820 \\
$\mathrm{~K}, \mathrm{mg} / \mathrm{dl}$ & 25.30 & 24.31 & 24.70 & 0.81 & 0.6816 \\
$\mathrm{Na}, \mathrm{mg} / \mathrm{dl}$ & $236.47^{\mathrm{a}}$ & $275.86^{\mathrm{b}}$ & $241.19^{\mathrm{a}}$ & 9.76 & 0.0096 \\
\hline
\end{tabular}

${ }^{1} \mathrm{PTH}$ - parathyroid hormone, ${ }^{2} \mathrm{Hy}$ - hydroxyproline

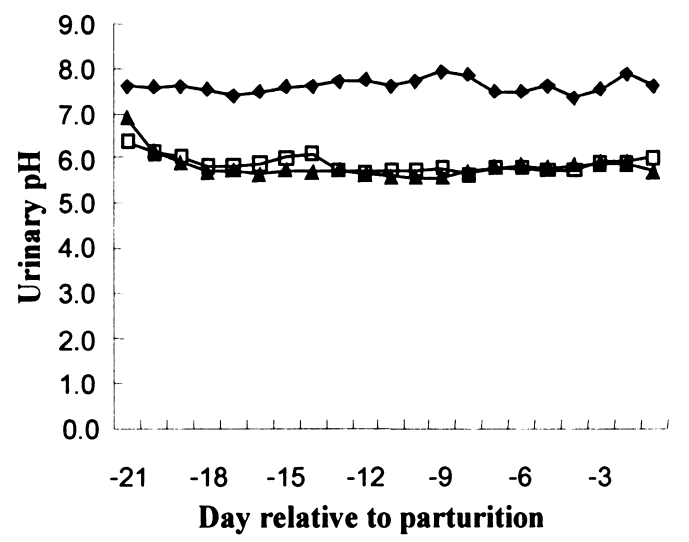

Figure 2. Urinary $\mathrm{pH}$ as affected by treatments

As expected, urinary $\mathrm{pH}$ values were reduced by dietary anionic salts (Table 2; $\mathrm{P}<0.0001)$. The $\mathrm{pH}$ values of DCAD-2 and DCAD-10 were not significantly different $(\mathrm{P}>0.05)$. This result indicated that the inclusion of anionic salts with a DCAD value of $-10 \mathrm{meq} / 100 \mathrm{~g}$ DM of the total ration may be adequate to induce dry cow sub-acute acidosis and to increase the serum Ca content under the condition that reed hay and maize silage being the major forages. 


\section{CONCLUSIONS}

These data indicate that a diet based on reed hay and maize silage supplemented with gelatinized anionic salts with maize starch and molasses with a dietary cation-anion difference value of $-9.64 \mathrm{meq} / 100 \mathrm{~g}$ DM is suitable for prepartum dairy cows. Furthermore, such a diet is beneficial due to its capacity to increase periparturient $\mathrm{Ca}$ in serum and without reduction of dry matter intake.

\section{REFERENCES}

Bartels H., Boemer M., Heirli C., 1972. Serum creatinine determination without deproteinization. Clin. Chim. Acta 37, 193-197

Beede D.K., Risco C.A., Donovan G.A., Wang C., Archbald L.F., Sanchez W.K., 1992. Nutritional management of the late pregnant dry cow with particular reference to dietary cation-anion difference and calcium supplementation. In: Proceedings of 24th Annual Conference. Amer. Assn. Bovine Practitioners. Orlando, FL Frontier Printers, Stillwater, OK, pp. 51-55

Dabev D., Struck H., 1971. Microliter determination of free hydroxyproline in blood serum. Biochem. Med. 5, 17-21

Fredeen A.H., DePeters E.J., Baldwin R.L., 1988. Characterization of acid-base disturbances and the effects on calcium and phosphorus balances of dietary fixed ions in pregnant or lactating does. J. Anim. Sci. 66, 159-173

Goff J.P., Horst R.L., Beitz D.C., Littledike E.T., 1988. Use of 24-F-1,25-dihydroxy-vitamin $\mathrm{D}_{3}$ to prevent parturient paresis in dairy cows. J. Dairy Sci. 71, 1211-1219

Joyce P. W., Sanchez W .K., Goff J.P., 1997. Effect of anionic salts in prepartum diets based on alfalfa. J. Dairy Sci. 80, 2866-2875

Oetzel G.R., Barmore J.A., 1993. Intake of a concentrate mixture containing various anionic salts fed to pregnant, non-lactating cows. J. Dairy Sci. 76, 1617-1623

SAS, 1985. User's Guide: Statistics, Version 5 Edition. SAS Institute Inc. Cary, NC

Weissman N., Pileggi V.J., 1974. Inorganic ions. In: R.J. Henry, D.C. Cannon, J.W. Winkelman (Editors). Clinical Chemistry: Principles and Technics. Harper \& Row, Hagerstown, MD, pp. $637-754$ 